\title{
Improving crop mineral nutrition
}

\author{
Philip J. White • Timothy S. George • \\ John P. Hammond • Euan K. James
}

Received: 25 August 2014 / Accepted: 5 October 2014 / Published online: 12 October 2014

(C) Springer International Publishing Switzerland 2014

\begin{abstract}
Background Crops require adequate nutrition for the production of food, fibre and fuel, but soil conditions often limit the ability of crops to acquire mineral nutrients. To address this, mineral nutrients can be applied as inorganic or organic fertilisers to the soil or as liquid fertilisers to foliage. However, production and use of fertilisers can have negative environmental impacts. The articles in this Special Issue illustrate a number of ways to improve nutrient acquisition from the soil and their delivery through foliar application.

Scope Articles highlighted here include those that discuss ways by which to assess a crop's requirement for additional mineral elements, ways by which minerals can be supplied more effectively to crops both through roots and shoots, and ways by which the crop itself can be enhanced to acquire more mineral elements.

Conclusions It is apparent from the information contained in this Special Issue that to improve the ability of crops to acquire mineral elements, a number of strategies are available. However, the success of any one intervention is dependent on how these strategies
\end{abstract}

Responsible Editor: Ismail Cakmak.

P. J. White $(\bowtie) \cdot$ T. S. George • E. K. James

The James Hutton Institute,

Invergowrie, Dundee DD2 5DA, UK

e-mail: philip.white@hutton.ac.uk

J. P. Hammond

School of Agriculture, Policy and Development,

University of Reading,

Whiteknights, PO Box 237, Reading RG6 6AR, UK interact with the environment in which they are deployed and the suitability of the management system for the specific intervention.

Keywords Essential elements · Fertiliser · Nutrient availability · Phosphorus · Plant-microbe interactions . roots

\section{Background}

Crop production requires adequate availability of the 14 essential mineral elements (mineral nutrients) necessary for plant growth (White and Brown 2010). Low input agriculture is generally limited by the phytoavailability of N, K, P or S, whilst the phytoavailability of Fe, Zn and $\mathrm{Cu}$ often limits crop production on alkaline and calcareous soils, that of $\mathrm{K}, \mathrm{P}, \mathrm{Mg}, \mathrm{Ca}$ or Mo limits crop production on acid soils, and that of $\mathrm{B}$ can limit crop production on soils with various $\mathrm{pH}$ (Fageria et al. 2011; Mueller et al. 2012; White et al. 2013a). To address such limitations to crop production, mineral nutrients can be applied as inorganic or organic fertilisers to the soil (Fageria et al. 2011; White et al. 2012) or as liquid fertilisers to foliage (Fernández et al. 2013). However, the production and use of fertilisers can have a variety of negative environmental consequences, including the production of greenhouse gasses, deterioration of soil and water quality, and the exhaustion of non-renewable resources (White and Brown 2010; White et al. 2013b). Thus, it is necessary to optimise the efficiency with which mineral elements are acquired by crops and 
utilised physiologically for the production of food, fibre and fuel (White et al. 2013b). In this Special Issue, which complements a Special Issue edited by Schjørring and Cakmak (2014), we collect together a range of articles that demonstrate a number of approaches at our disposal to improve nutrient acquisition from the soil by plants and delivery of mineral nutrients through foliar applications to plants. Collectively, these articles demonstrate the importance of understanding how our interventions interact with the wider environment and the management systems in which they are deployed.

\section{Improving nutrient acquisition from the soil}

In the soil, all mineral elements move by a combination of mass flow and diffusion, and all strategies designed to improve mineral acquisition by crops affect one or both of these processes (Lynch 2007; Richardson et al. 2011; Simpson et al. 2011; White et al. 2013a). Diffusion of mineral elements is determined by the concentration gradients between the root surface and the soil solution (White and Greenwood 2013), which are often dictated by interactions with soil mineral surfaces. It operates over short distances, and is especially important for the macronutrients $\mathrm{P}$ and $\mathrm{K}$ that often limit crop production (Hinsinger et al. 2011). The mass flow of a mineral element to the root surface is determined by its concentration in the soil solution and the transpiration-driven movement of water to the root surface (White and Greenwood 2013). It is important for the acquisition of essential mineral elements with large concentrations in the soil solution, such as $\mathrm{N}, \mathrm{K}, \mathrm{S}, \mathrm{Ca}, \mathrm{Mg}$ and $\mathrm{Cl}$ in agricultural soils, and for mineral elements that are required in relatively small quantities by plants, such as $\mathrm{Fe}, \mathrm{Mn}, \mathrm{Zn}, \mathrm{Cu}, \mathrm{Ni}, \mathrm{B}$ and Mo (White et al. 2013a).

If essential mineral elements are not present, or not phytoavailable, in the soil, then they must be supplied as fertilisers to enable crop production and ensure produce quality. Many agronomic strategies can be adopted to increase the efficiency with which inorganic and organic fertilisers are used to provide the essential mineral elements required by crops (Simpson et al. 2011). In principle, these optimise the chemistry, quantity, placement, and timing of fertiliser applications (Fageria et al. 2011; Simpson et al. 2011; Mueller et al. 2012; Noack et al. 2012; White et al. 2012; White and Greenwood 2013). The chemical form and quantity of a mineral element required for crop production in a particular location depends critically on soil characteristics. Many fertiliser recommendations are based on estimating the phytoavailability of mineral elements in the soil (e.g. Defra 2010). In this Special Issue, Włodarczyk et al. (2014) describe the development of a technique to determine the phytoavailability of B in agricultural soils, whilst Suriyagoda et al. (2014) provide a case study of how soil characteristics, fertiliser chemistry and quantity, and the environment interact. In the latter, the authors studied the benefits of incorporating straw on the growth of rice plants in either clay or sandy soils under a range of moisture conditions. They observed that incorporating straw increased plant growth in clay soils, but not those grown in sandy soils, and only when adequate $\mathrm{P}$ was supplied. This paper provides a good demonstration of the importance of understanding interactions between environment and management.

Agronomic strategies can be complemented by cultivating genotypes with appropriate below ground traits for nutrient acquisition (Lynch 2007, 2011, 2013; Richardson et al. 2011; White et al. 2012, 2013a, b). Below ground traits that influence the acquisition of mineral elements by plants include, (1) root characteristics, such as root elongation rate, lateral root production, specific root length (length/mass quotient), root length density (root length / soil volume), reduced metabolic load of roots (aerenchyma formation) and root hair length and abundance, all of which increase the volume of soil explored by the root system and the surface area for the uptake of mineral elements, (2) the proliferation of roots in discrete patches of soil containing greater concentrations of mineral elements, such as topsoil horizons rich in organic matter, (3) modification of rhizosphere $\mathrm{pH}$ and the exudation of low molecular weight organic solutes and/or enzymes, which influence the concentration of mineral elements in the soil solution, (4) high-capacity uptake systems for mineral nutrients, and (5) interactions with microbes either intimately, through mycorrhizal associations or nodulation by rhizobia, or loosely, through the culture of beneficial microbes or exclusion of detrimental microbes in the rhizosphere. None of these below ground traits work in isolation of one another and it is, therefore, important to consider (1) how they interact with one another (Brown et al. 2013), (2) how they interact with the environment (Oburger et al. 2011; Jin et al. 2012), and (3) how they interact with crop management practices (George et al. 2011; Nazeri et al. 2013). 
Two papers in this Special Issue investigate how the acquisition of mineral elements is influenced by the rhizosphere environment. In one of these, Tanoi et al. (2014) demonstrate that $\mathrm{Mg}$ uptake by rice roots is mediated by both high-affinity and low-affinity transport systems, whose capacities increase with Mg starvation and return rapidly to a basal levels after $\mathrm{Mg}$ resupply. This work demonstrates that the Mg uptake system of rice roots is tightly regulated and reacts rapidly to changes in the rhizosphere environment. In the second example, Watts-Williams and Cavagnaro (2014) describe a meta-analysis of studies on nutrient uptake by a wild-type and an arbuscular mycorrhizal fungi (AMF)defective tomato mutant $(r m c)$ and go on to demonstrate that colonisation by AMF significantly affects the uptake of many mineral nutrients. They also observe that soil $\mathrm{P}$ and $\mathrm{Zn}$ phytoavailability influences the ability of mycorrhizal plants to acquire other mineral nutrients, with deficient plants having greater AMF colonisation, which assists mineral uptake.

\section{Delivering mineral nutrients through foliar fertilisers}

Foliar applications of mineral elements can be used both in combination with applications to soil or, for elements required in small amounts (i.e. micronutrients), as an alternative to soil applications (Fageria et al. 2009; Defra 2010; White and Greenwood 2013; Eichert and Fernández 2012; Fernández et al. 2013). The use of foliar fertilisers is not novel, and has been common practice in agriculture and horticulture for many decades (Fageria et al. 2009; Kannan 2010; Fernández et al. 2013). It is particularly effective in delivering (1) mineral nutrition when soil applications are impractical, such as when the topsoil is dry, (2) mineral elements with restricted phytoavailability in the soil, such as $\mathrm{Zn}$, $\mathrm{Fe}, \mathrm{Cu}$ and $\mathrm{Mn}$ in alkaline and calcareous soils, and (3) mineral elements required in large amounts during periods of great demand, such as N, P, K and S (Fageria et al. 2009; Eichert and Fernández 2012; White et al. 2012; Fernández et al. 2013; White and Greenwood 2013). In addition, it has the advantage over soil applications of mineral fertilisers in that it provides the opportunity to deliver appropriate amounts of specific mineral elements to particular tissues at particular developmental stages. Thus, it can be used (1) to improve the physical and nutritional quality of produce in a targeted fashion (White and Broadley 2011; Eichert and Fernández 2012; Fernández et al. 2013), (2) to correct mineral deficiencies as and when they occur (Fageria et al. 2009; Defra 2010; Eichert and Fernández 2012; Fernández et al. 2013), (3) to address mineral deficiencies of phloem-immobile elements in phloem-fed tissues, such as fruits (Ho and White 2005; Fageria et al. 2009; Eichert and Fernández 2012; Fernández et al. 2013) and (4) to minimise absolute fertiliser requirements, thereby reducing losses of mineral elements to the wider environment (Kannan 2010; Eichert and Fernández 2012; White et al. 2012; Fernández et al. 2013). Remedial applications of foliar fertilisers are often made when crops exhibit visible mineral deficiency symptoms. Traditionally, these are recorded by growers during crop walking, but crops could be monitored remotely and their nutritional status diagnosed using modern image analysis techniques, such as those described by Hong et al. (2014), in this Special Issue, to identify the $\mathrm{N}$ nutritional status of watermelon. Since foliar fertilisers can be applied with other foliar chemicals, financial costs can also be reduced.

The most effective use of foliar fertilisers can be achieved using responsive genotypes, which can take up mineral elements efficiently into shoot tissues and retranslocate them appropriately. Mineral elements supplied as foliar fertilisers enter the leaf across the cuticle or through open stomata (Fageria et al. 2009; Kannan 2010; Eichert and Fernández 2012; Fernández et al. 2013). The relative contributions of each pathway to the uptake of mineral elements are debated, but will depend upon both the form in which the element is supplied and leaf surface properties (Eichert and Fernández 2012). Two articles in this Special Issue address the effects of leaf characteristics on the absorption and delivery of $\mathrm{P}$ to reproductive tissues of wheat (Triticum aestivum L.). Peirce et al. (2014) observe that greater $\mathrm{P}$ accumulation in the ear of wheat following foliar application to adaxial, compared to abaxial, leaf surfaces, is directly related to stomatal density, although they concede that trichome density and cuticular composition might also influence $\mathrm{P}$ uptake, whilst Fernández et al. (2014) observe that $\mathrm{P}$ absorption is affected by leaf $\mathrm{P}$ status, with more $\mathrm{P}$ being absorbed by leaves of P-replete plants than by those of P-deficient plants. They attribute the latter phenomenon to impaired stomatal functioning and a reduction in stomatal density in leaves of P-deficient plants. It is commonly observed 
that the uptake of mineral elements applied to leaves is related to stomatal abundance (Fernández et al. 2013), but the effects of nutritional status on stomatal density and functioning are rarely studied (Cramer et al. 2009; Waraich et al. 2011; Wimmer and Eichert 2013; Rothwell and Dodd 2014). Since there is considerable genetic variation in stomatal density, trichome density and cuticular chemical composition within plant species (e.g. Araus et al. 1991; Sadras et al. 2012; Chitwood et al. 2013; Khazaei et al. 2013; Parsons et al. 2013; Zhang et al. 2013; Bloomer et al. 2014; Doroshkov et al. 2014; Ray et al. 2014), there exists the possibility to select or breed for genotypes with improved response to foliar fertilisers.

The ability to re-translocate mineral elements applied as foliar fertilisers to deficient or developing tissues is essential for preventing contemporaneous and future mineral deficiencies within the plant. However, mineral deficiencies often limit the re-translocation of mineral elements (Hermans et al. 2006; Fernández et al. 2013), especially those with limited phloem mobility, which necessitates direct and repeated application of foliar fertilisers to deficient tissues (Fernández et al. 2013). In addition, it has also been hypothesised that the translocation of mineral elements within the plant might alleviate the effects of toxic mineral elements by promoting dilution through redistribution, increased growth, biochemical competition, or co-precipitation in non-vital compartments. In this Special Issue, Iqbal (2014) has tested, and disproven, the hypothesis that the translocation of $\mathrm{P}$ from roots grown in aluminium (Al)-free soil can alleviate Al-toxicity in roots of the same plant exposed to toxic soil $\mathrm{Al}$ concentrations using a split-root system.

\section{Conclusions}

It is apparent from the information contained in this Special Issue that in order to improve the ability of crops to acquire mineral elements, a number of strategies are available. These include better monitoring of nutrient status, improved formulations of fertilisers, access to alternative sources of nutrients, better agronomy and improved genotypes for nutrient use and better understanding of the physiology of uptake of nutrients through both roots and shoots. However, the success of any one intervention is dependent on how these strategies interact with the environment in which they are deployed and the suitability of the management system for the specific intervention.

Acknowledgments This work was supported by the Rural and Environment Science and Analytical Services Division (RESAS) of the Scottish Government.

\section{References}

Araus JL, Febrero A, Vendrell P (1991) Epidermal conductance in different parts of durum-wheat grown under mediterranean conditions - the role of epicuticular waxes and stomata. Plant Cell Environ 14:545-558

Bloomer RH, Lloyd AM, Symonds VV (2014) The genetic architecture of constitutive and induced trichome density in two new recombinant inbred line populations of Arabidopsis thaliana: phenotypic plasticity, epistasis, and bidirectional leaf damage response. BMC Plant Biol 14:119. doi:10. 1186/1471-2229-14-119

Brown LK, George TS, Barrett GE, Hubbard SF, White PJ (2013) Interactions between root hair length and arbuscular mycorrhizal colonisation in phosphorus deficient barley (Hordeum vulgare). Plant Soil 372:195-205

Chitwood DH, Kumar R, Headland LR, Ranjan A, Covington MF, Ichihashi Y, Fulop D, Jimenez-Gomez JM, Peng J, Maloof JN, Sinha NR (2013) A quantitative genetic basis for leaf morphology in a set of precisely defined tomato introgression lines. Plant Cell 25:2465-2481

Cramer MD, Hawkins HJ, Verboom GA (2009) The importance of nutritional regulation of plant water flux. Oecologia 161:1524

Department for Environment, Food and Rural Affairs [Defra] (2010) Fertiliser manual (RB209), 8th edn. The Stationery Office, London

Doroshkov AV, Afonnikov DA, Pshenichnikova TA (2014) Genetic analysis of leaf pubescence in isogenic lines of bread wheat Novosibirskaya 67. Russ J Genet 50:153-160

Eichert T, Fernández V (2012) Uptake and release of elements by leaves and other aerial plant parts. In: Marschner P (ed) Marschner's mineral nutrition of higher plants, 3rd edn. Academic, San Diego, pp 71-84

Fageria NK, Barbosa MP, Moreira A, Guimaraes CM (2009) Foliar fertilization of crop plants. J Plant Nutr 32:1044-1064

Fageria NK, Baligar VC, Jones CA (2011) Growth and mineral nutrition of field crops. CRC Press, Boca Raton, FL

Fernández V, Sotiropoulos T, Brown P (2013) Foliar fertilization: scientific principles and field practices. International Fertilizer Industry Association, Paris, France

Fernández V, Guzmán P, Peirce CAE, McBeath TM, Khayet M, McLaughlin MJ (2014) Effect of wheat phosphorus status on leaf surface properties and permeability to foliar-applied phosphorus. Plant Soil. doi:10.1007/s11104-014-2052-6

George TS, Brown LK, Newton AC, Hallett PD, Sun BH, Thomas WTB, White PJ (2011) Impact of soil tillage on the robustness of the genetic component of variation in phosphorus $(\mathrm{P})$ use efficiency in barley (Hordeum vulgare L.). Plant Soil 339:113-123 
Hermans C, Hammond JP, White PJ, Verbruggen N (2006) How do plants respond to nutrient shortage by biomass allocation? Trends Plant Sci 11:610-617

Hinsinger P, Brauman A, Devau N, Gérard F, Jourdan C, Laclau JP, Le Cadre E, Jaillard B, Plassard C (2011) Acquisition of phosphorus and other poorly mobile nutrients by roots. Where do plant nutrition models fail? Plant Soil 348:29-61

Ho L, White PJ (2005) A cellular hypothesis for the induction of blossom-end rot in tomato fruit. Ann Bot 95:571-581

Hong J, Huang X, Ge M, Zhang L, Wang S, Du L, Lian Z, Chen G (2014) Application of digital image technique to diagnose $\mathrm{N}$ nutrition status of watermelon. Plant Soil, under revision

Iqbal T (2014) A split-root experiment shows that translocated phosphorus does not alleviate aluminium toxicity within plant tissue. Plant Soil. doi:10.1007/s11104-013-1962-z

Jin J, Tang C, Armstrong R, Sale P (2012) Phosphorus supply enhances the response of legumes to elevated $\mathrm{CO}_{2}(\mathrm{FACE})$ in a phosphorus-deficient vertisol. Plant Soil 358:91-104

Kannan S (2010) Foliar fertilization for sustainable crop production. Sustain Agric Rev 4:371-402

Khazaei H, Street K, Santanen A, Bari A, Stoddard FL (2013) Do faba bean (Vicia faba L.) accessions from environments with contrasting seasonal moisture availabilities differ in stomatal characteristics and related traits? Genet Res Crop Evol 60: 2343-2357

Lynch JP (2007) Roots of the second green revolution. Aust J Bot 55:493-512

Lynch JP (2011) Root phenes for enhanced soil exploration and phosphorus acquisition: tools for future crops. Plant Physiol 156:1041-1049

Lynch JP (2013) Steep, cheap and deep: an ideotype to optimize water and $\mathrm{N}$ acquisition by maize root systems. Ann Bot 112: 347-357

Mueller ND, Gerber JS, Johnston M, Ray DK, Ramankutty N, Foley JA (2012) Closing yield gaps through nutrient and water management. Nature 490:254-257

Nazeri NK, Lambers H, Tibbett M, Ryan MH (2013) Do arbuscular mycorrhizas or heterotrophic soil microbes contribute toward plant acquisition of a pulse of mineral phosphate? Plant Soil 373:699-710

Noack SR, McLaughlin MJ, Smernik RJ, McBeath TM, Armstrong RD (2012) Crop residue phosphorus: speciation and potential bio-availability. Plant Soil 359:375-385

Oburger E, Jones DL, Wenzel WW (2011) Phosphorus saturation and $\mathrm{pH}$ differentially regulate the efficiency of organic acid anion-mediated $\mathrm{P}$ solubilization mechanisms in soil. Plant Soil 341:363-382

Parsons EP, Popopvsky S, Lohrey GT, Alkalai-Tuvia S, Perzelan Y, Bosland P, Bebeli PJ, Paran I, Fallik E, Jenks MA (2013) Fruit cuticle lipid composition and water loss in a diverse collection of pepper (Capsicum). Physiol Plant 149:160-174

Peirce CAE, McBeath TM, Fernández V, McLaughlin MJ (2014) Wheat leaf properties affecting the uptake and translocation of foliar applied phosphorus. Plant Soil. doi:10.1007/s11104$014-2245-z$

Ray S, Tah J, Laskar S, Sinhababu A (2014) Study of genotypic variation of cultivars of winged bean [Psophocarpus tetragonolobus (Stickm.) DC.] with the help of n-alkane profile. Plant Syst Evol 300:209-215

Richardson AE, Lynch JP, Ryan PR, Delhaize E, Smith FA, Smith SE, Harvey PR, Ryan MH, Veneklaas EJ, Lambers H,
Oberson A, Culvenor RA, Simpson RJ (2011) Plant and microbial strategies to improve the phosphorus efficiency of agriculture. Plant Soil 349:121-156

Rothwell SA, Dodd IC (2014) Xylem sap calcium concentrations do not explain liming-induced inhibition of legume gas exchange. Plant Soil. doi:10.1007/s11104-014-2118-5)

Sadras VO, Lawson C, Montoro A (2012) Photosynthetic traits in Australian wheat varieties released between 1958 and 2007. Field Crops Res 134:19-29

Schjørring JK, Cakmak I (2014) Plant mineral nutrition for nutrient and food security. Physiol Plant 151:199

Simpson RJ, Oberson A, Culvenor RA, Ryan MH, Veneklaas EJ, Lambers H, Lynch JP, Ryan PR, Delhaize E, Smith FA, Smith SE, Harvey PR, Richardson AE (2011) Strategies and agronomic interventions to improve the phosphorus-use efficiency of farming systems. Plant Soil 349:89-120

Suriyagoda L, De Costa WAJM, Lambers H (2014) Growth and phosphorus nutrition of rice when inorganic fertiliser application is partly replaced by straw under varying moisture availability in sandy and clay soils. Plant Soil. doi:10.1007/ s11104-014-2049-1

Tanoi K, Kobayashi NI, Saito T, Iwata N, Kamada R, Iwata R, Suzuki H, Atsushi H, Yoshimi O, Ryohei S, Nakanishi TM (2014) Effects of magnesium deficiency on magnesium uptake activity evaluated using ${ }^{28} \mathrm{Mg}$ as a tracer. Plant Soil. doi: 10.1007/s11104-014-2197-3

Waraich EA, Ahmad R, Saifullah, Ashraf MY, Ehsanullah (2011) Role of mineral nutrition in alleviation of drought stress in plants. Aust J Crop Sci 5:764-777

Watts-Williams SJ, Cavagnaro TR (2014) Nutrient interactions and arbuscular mycorrhizas: a meta-analysis of a mycorrhiza-defective mutant and wild-type tomato genotype pair. Plant Soil. doi:10.1007/s11104-014-2140-7

White PJ, Broadley MR (2011) Physiological limits to zinc biofortification of edible crops. Front Plant Sci 2:80. doi:10. 3389/fpls.2011.00080

White PJ, Brown PH (2010) Plant nutrition for sustainable development and global health. Ann Bot 105:1073-1080

White PJ, Greenwood DJ (2013) Properties and management of cationic elements for crop growth. In: Gregory PJ, Nortcliff S (eds) Soil conditions and plant growth. Blackwell Publishing, Oxford, pp 160-194

White PJ, Broadley MR, Gregory PJ (2012) Managing the nutrition of plants and people. Appl Environ Soil Sci 2012: 104826. doi:10.1155/2012/104826

White PJ, George TS, Dupuy LX, Karley AJ, Valentine TA, Wiesel L, Wishart J (2013a) Root traits for infertile soils. Front Plant Sci 4:193. doi:10.3389/fpls.2013.00193

White PJ, George TS, Gregory PJ, Bengough AG, Hallett PD, McKenzie BM (2013b) Matching roots to their environment. Ann Bot 112:207-222

Wimmer MA, Eichert T (2013) Review: mechanisms for boron deficiency-mediated changes in plant water relations. Plant Sci 203:25-32

Włodarczyk W, Spiak Z, Piszcz U, Gediga K, Bielecki K (2014) Different extraction methods for phytoavailable boron determination in oilseed rape. Plant Soil, under revision

Zhang XF, Chen XH, Chen B, Han HL, Geng SS (2013) Genetic analysis of trichome density on the main stem and leaves in a recombinant inbred lines population derived from wild pepper (Capsicum annuum L.). J Agric Biotechnol 21:407-412 